\title{
October Highlights
}

\section{Dementia}

Miller et al. (p. 978), presenting the remarkable artwork of five patients, demonstrate the superior artistic skill that may characterize frontotemporal dementia. Jack et al. (p. 993) performed volumetric MRI studies showing that temporal lobe atrophy occurs in normal aging individuals but that the atrophy in patients with $\mathrm{AD}$ progresses at a rate 2.5 times faster.

- Swan et al. (p. 986) used blood pressure data from a study that began almost 30 years ago to assess the relation of blood pressure to cognitive decline and MRI-determined brain volume. They found an association between midlife systolic blood pressure (SBP) and late-life cognitive decline in a longitudinal study of 392 patients. High midlife SBP also predicted MRI findings of cerebral atrophy and white matter hyperintensities. Jagust et al. (p. 1009) studied regional cerebral blood flow (rCBF) using SPECT in patients with $\mathrm{AD}$, and found an association between preserved right parietal $\mathrm{rCBF}$ and longer survival.

\section{Sleep}

Diomedi et al. (p. 1051), in studies using transcranial Doppler, found that obstructive sleep apnea is associated with less cerebral vasodilation in response to breath holding in studies using transcranial Doppler. This impairment of vascular reactivity may contribute to the greater risk of stroke in these patients.

\section{Movement disorders}

Lieberman et al. (p. 1057) studied the role of the dopamine agonist ropinirole in reducing L-dopa dose and "off" time in advanced $\mathrm{PD}$ with motor fluctuations. - Ondo et al. (p. 1063) report the use of electrical stimulation of the ventral thalamus to reduce contralateral arm tremor in patients with essential tremor or with $\mathrm{PD}$; they found significant improvement in both groups of patients. Bennett et al. (p. 982) show a link between a dinucleotide repeat in the gene for the microtubule-associated tau protein and progressive supranuclear palsy (PSP); the Ao allele was more common in PSP patients than in healthy controls or patients with multiple system atrophy.

\section{Neuromuscular disease}

Offen et al. (p. 1100) revisit the issue of an autoimmune mechanism contributing to the pathogenesis of ALS. Using an in vitro functional assay, they found that antibodies from the serum of ALS patients block L-type calcium channels. Greater channel inhibition was correlated with increasing disease duration.

- Papadimitriou et al. (p. 1086) studied three siblings with mitochondrial neurogastrointestinal encephalopathy (MNGIE), noting that mitochondrial DNA (mtDNA) deletions and mtDNA depletion suggest a defect in replication and stabilization control of mitochondria. $-\mathrm{Vu}$ et al. (p. $11.90)$ studied a 29 -year-old woman with lifelong myopathy, and found that depleted levels of mitochondrial DNA do not preclude long-term survival. $\bullet$ Benton et al. (p. 1081) report an association between CAG repeats on chromosome $3 p$ 12-13 and the progressive pigmentary macular dystrophy that defines spinocerebellar ataxia type 7 . - Himuro et al. (p. 1195) describe a distal sensory axonopathy attributable to the nerve gas sarin inhaled during the terrorist attack on the Tokyo subway system. Pathologic findings support dying-back degeneration.

\section{Oncology}

Landolfi et al. (p. 1136) report 5 -year survival in $45 \%$ of adults with brainstem gliomas; their median survival of 54 months was significantly longer than that in children with brainstem gliomas. These tumors may be less aggressive in adults than in children. van den Bent et al. (p. 1140) assessed an intensified chemotherapeutic approach to oligodendrogliomas. The overall median progression time of 10 months for all patients was extended to 12 months in $46 \%$ and 25 months in $17 \%$ of patients.

\section{Demyelinating disease}

Mandler et al. (p. 1219) report that use of prednisone and azathioprine in seven patients with newly diagnosed Devic's disease (neuromyelitis optica) improved function and prevented relapses over an 18-month follow-up. This report suggests that this approach warrants further study. 


\title{
Neurology ${ }^{\circ}$
}

\author{
October Highlights \\ Neurology 1998;51;934 \\ DOI 10.1212/WNL.51.4.934
}

This information is current as of October 1, 1998

$\begin{array}{ll}\begin{array}{l}\text { Updated Information \& } \\ \text { Services }\end{array} & \begin{array}{l}\text { including high resolution figures, can be found at: } \\ \text { http://n.neurology.org/content/51/4/934.full }\end{array} \\ \text { Permissions \& Licensing } & \begin{array}{l}\text { Information about reproducing this article in parts (figures,tables) or in its } \\ \text { entirety can be found online at: } \\ \text { http://www.neurology.org/about/about_the_journal\#permissions }\end{array} \\ & \begin{array}{l}\text { Information about ordering reprints can be found online: } \\ \text { http://n.neurology.org/subscribers/advertise }\end{array}\end{array}$

Neurology ${ }^{\circledR}$ is the official journal of the American Academy of Neurology. Published continuously since 1951, it is now a weekly with 48 issues per year. Copyright. All rights reserved. Print ISSN: 0028-3878. Online ISSN: $1526-632 X$. 